\title{
A Review of Omacetaxine: A Chronic Myeloid Leukemia Treatment Resurrected
}

Eric S. Winer · Daniel J. DeAngelo

Received: November 29, 2017 / Published online: March 15, 2018

(C) The Author(s) 2018

\section{ABSTRACT}

The paradigm of targeted therapy was pioneered for chronic myeloid leukemia (CML). The advent of tyrosine kinase inhibitors (TKIs) has led to marked improvements in responses and overall survival; however, there is still a subset of patients that are either resistant through a multitude of mechanisms or intolerant to standard TKI therapy. Omacetaxine mepesuccinate (omacetaxine), a semisynthetic purified homoharringtonine compound, has been studied for over 40 years and was approved in 2012 by the Food and Drug Administration (FDA) for patients with CML refractory or intolerant to two or more TKIs. Omacetaxine has a novel mechanism of action-inhibition of protein synthesis, which does not overlap with kinase inhibition. Multiple studies have demonstrated that omacetaxine can achieve responses in heavily treated patients with either chronic-phase or accelerated-phase CML,

Enhanced content To view enhanced content for this article go to https://doi.org/10.6084/m9.figshare. 5944120 .

E. S. Winer $(\varangle) \cdot$ D. J. DeAngelo

Adult Leukemia Program, Department of Medical Oncology, Dana-Farber Cancer Institute, Boston, MA, USA

e-mail: EricS_Winer@DFCI.HARVARD.EDU regardless of the presence of mutations in the tyrosine kinase domain. This review will outline the tortuous story of omacetaxine, including preclinical and clinical studies of homoharringtonine, current indications, and management guidelines.

Keywords: Chronic myeloid leukemia; Omacetaxine; Tyrosine kinase inhibitors

\section{INTRODUCTION}

Chronic myeloid leukemia (CML) is a clonal hematopoietic stem cell disorder characterized by the Philadelphia chromosome, first identified in the early 1960s by Nowell and Hungerford [1]. Thirty years later, the gene product $b c r-$ $a b l$ of the chromosomal translocation $t(9 ; 22)(\mathrm{q} 34 ; \mathrm{q} 11)$ was demonstrated to cause constitutively active tyrosine kinase activity leading to the CML phenotype [2, 3]. The treatment of CML has undergone multiple transformations, from the early uses of interferon to the birth of targeted therapies manifested in tyrosine kinase inhibitors. Omacetaxine, the focus of this review, has spanned these decades in search of a position in the treatment algorithm. 


\section{INITIAL DATA FOR HOMOHARRINGTONINE AND OMACETAXINE}

Omacetaxine mepesuccinate (omacetaxine) is a semisynthetic purified homoharringtonine (HHT) compound that has had a tortuous route to approval; it has been described as holding "the dubious record for the longest time of development of an anticancer agent until FDA approval, almost 40 years" [4]. HHT, a plant alkaloid from Cephalotaxus species, was first described by Chinese investigators as an antileukemic agent for AML [4], with complete response rates approaching $25 \%$. Further studies in AML patients in the United States with varying dosing schedules demonstrated complete response rates varying from 0\% (50\% hypoplasia) to $25 \%$ [5-8]. Additionally, multiple regimens combining HHT with conventional chemotherapy, mainly studied in China, have produced mixed results, based on a 2015 meta-analysis [9]. Single-agent antileukemic activity was also noted in polycythemia vera, CNS leukemia [4], and myelodysplastic syndrome [10].

Initial studies evaluating HHT in CML were predominantly performed in the 1990s (Table 1). In the initial study with chronicphase CML patients, HHT $2.5 \mathrm{mg} / \mathrm{m}^{2}$ was given as a 14-day continuous infusion for remission induction followed by a 7-day maintenance course each month. Thirty-one percent of patients developed a cytogenetic response, with 15\% having a MCyR and 7\% achieving a CCyR. The most common adverse effects were neutropenia and thrombocytopenia, predominantly seen in the induction phase. Severe myelosuppression was addressed in subsequent cycles with dose reductions by decreasing the number of days that HHT was infused. The continuous infusion seemed to abrogate the cardiac and hypotension side effects noted in previous studies that used bolus dosing [11].

Further studies evaluated HHT with interferon both sequentially and concomitantly. The first study administered HHT according to the same induction and maintenance schedule as previously described, but after 6 cycles converted them to an interferon-alpha regimen at 5 $\mathrm{MU} / \mathrm{m}^{2}$. After 6 courses of HHT, the major, minor, and complete cytogenetic responses were $33 \%, 23 \%$, and $4 \%$, respectively. After "consolidation" with IFN- $\alpha$, rates of complete, partial, and minor cytogenetic response were $23 \%, 21 \%$, and $21 \%$, respectively. The initial $5 \mathrm{MU} / \mathrm{m}^{2}$ dose proved highly myelosuppressive, and upon analysis the median dose of IFN- $\alpha$ delivered was found to be $2.4 \mathrm{MU} / \mathrm{m}^{2}$ after individual patient dose reductions. These results did not differ significantly from historical controls for IFN- $\alpha$ alone, although treatment with HHT led to a significant improvement in patients with splenomegaly [12].

Concomitant administration of HHT and IFN- $\alpha$ yielded better results. Due to the myelosuppressive toxicities of both drugs, the HHT was dosed at the standard $2.5 \mathrm{mg} / \mathrm{m}^{2}$ as a continuous infusion but only for 5 days, along with full-dose IFN- $\alpha\left(5 \mathrm{MU} / \mathrm{m}^{2}\right)$ simultaneously for 5 days. This combination produced a complete hematologic response (CHR) rate of $85 \%$, with complete and major cytogenetic response rates of $69 \%$ and $52 \%$, respectively [13].

Combinations with HHT and cytarabine were also evaluated. An early phase II study enrolled 105 patients treated with $2.5 \mathrm{mg} / \mathrm{m}^{2}$ as a continuous infusion for 5 days along with cytarabine at $7.5 \mathrm{mg} / \mathrm{m}^{2}$ twice daily for 5 days, with both drugs cycled every 4 weeks. The overall CHR was $72 \%$ with a cytogenetic response rate of $32 \%$. When comparative analysis was performed with historical controls, the combination of HHT plus cytarabine was found to yield similar response rates to HHT alone, but a significantly longer overall survival [14]. A second study treated 44 previously untreated chronic-phase CML patients with HHT at $2.5 \mathrm{mg} / \mathrm{m}^{2}$ daily with cytarabine $7.5 \mathrm{mg} / \mathrm{m}^{2}$ given continuously for 7 days on a 28-day cycle [15]. Eighty-two percent of the patients achieved a CHR, with only $17 \%$ of patients presenting a cytogenetic response. 


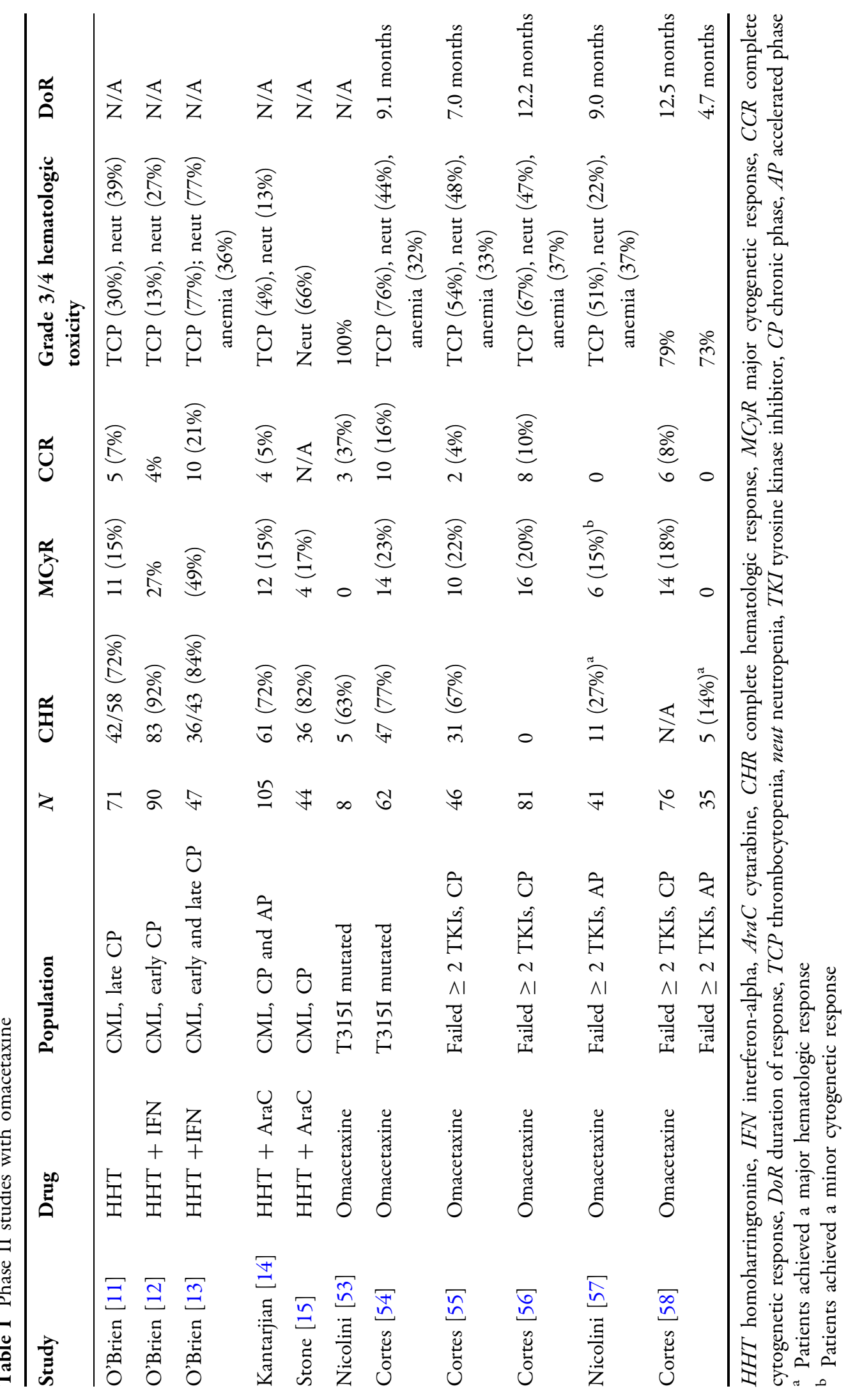


Table 2 Response rates to second- and third-generation TKIs of patients intolerant to previous treatment or with relapsed disease

\begin{tabular}{lllllll}
\hline & $\boldsymbol{N}$ & Res/intol & CHR (\%) & MCyR (\%) & CCyR (\%) & Follow-up \\
\hline Dasatinib [23] & 186 & $127 / 59$ & 90 & 52 & 39 & 8 months \\
Nilotinib [26] & 137 & $92 / 45$ & 74 & 48 & 31 & 6 months \\
Bosutinib [29] & 288 & $200 / 88$ & 86 & 53 & 41 & 24 weeks \\
Ponatinib [30] & 267 & $214 / 40^{\mathrm{a}}$ & N/A & 56 & 46 & 12 months \\
\hline
\end{tabular}

Res imatinib-resistant, intol imatinib-intolerant, $C H R$ complete hematologic response, $M C y R$ major cytogenetic response, $C C R$ complete cytogenetic response

${ }^{\text {a }}$ Resistant to nilotinib or dasatinib

\section{TKI THERAPY FOR THE TREATMENT OF CML IN RESISTANT DISEASE}

Despite the initial success of HHT in treating $\mathrm{CML}$, it was relegated to second-class status, as imatinib and the other tyrosine kinases commandeered the clinical landscape, including the entire CML population. Patients even abandoned homoharringtonine studies in order to use the novel and more targeted TKIs [16].

TKIs drastically changed the landscape of treatment for CML by providing novel targeted agents with minimal toxicity, especially when compared to interferon-alpha and SCT [17-19]. More importantly, imatinib had a favorable side-effect profile and led to an overall survival at 5 years of $89 \%$ [20] and at 10 years of $83.3 \%$ [21]. Unfortunately, approximately one-third of patients need to discontinue imatinib therapy; half of those discontinuations are due to intolerance and half are due to disease resistance by 6 years [22]. In spite of these exceptional responses to imatinib-based therapy, the discovery of more potent second-generation TKIs (dasatinib [23, 24], nilotinib $[25,26]$, and bosutinib [27-29]) and the third-generation TKI ponatinib $[30,31]$ for use in cases of refractory disease and drug intolerance has further improved outcomes for patients with CML (Table 2).

There are multiple causes of TKI resistance, with the most common being point mutations in the ATP-binding domain of the BCR-ABL protein complex which inhibit TKI binding [32]. Most of these point mutations can be circumvented by using an alternative TKI [33]; even the most refractory mutation, T315, is susceptible to ponatinib [34]. However, further resistance has occurred through the development of compound mutations within the kinase domain, encouraging the search for inhibitors that bind outside the ATP-binding domain [35]. In addition, ABL001 (asciminib) is a novel allosteric TKI that binds to the myristoyl pocket of ABL1, causing an inactive kinase conformation (ClinicalTrials.gov identifier: NCT02081378). It is being explored in a phase I trial for patients intolerant/refractory to standard TKI therapy. A second source of resistance that eludes the TKIs is mutations in signal transduction pathways, such as SRC, PI3 K, KRAS, JAK2, NFAT, and MEK [36]. Furthermore, low levels of the cellular influx pump for imatinib, organic-cation transporter-1 (OCT-1), directly affect intracellular availability, leading to imatinib resistance [37]. Also, increased BCR$A B L$ expression due to either duplication or upregulation of the oncogene transcript is associated with more advanced disease and the development of resistance [38].

Two situational changes occurred that led to the rebirth of HHT. The first was a need for a different agent than the TKIs. As previously stated, TKI resistance began to develop, and this resistance was seen against multiple TKIs due to their similar mechanisms of action via the ATPbinding domain [32, 33, 36]. Secondly, a novel semisynthetic version of HHT was formulated, which led to the rebranding of the drug through a new corporate sponsor, ChemGenex, and the 
promotion of several studies $[4,39]$. This new formulation, omacetaxine mepesuccinate, has moved forward in studies in the United States, although it should be noted that HHT is still used and studied in China and other countries.

\section{MECHANISM OF ACTION}

The main mechanism of action for omacetaxine is the inhibition of protein translation (Fig. 1). Normal protein translation is a complex process. mRNA is read by tRNA, which transfers the charged amino acid initially to the acceptor (A site) of the $40 \mathrm{~S}$ ribosome and subsequently transfers the amino acid chain to the incoming amino acid. The entire complex then travels to the peptidyl-tRNA (P site). Ultimately, the deacylated tRNA is moved to the E site, where it is removed from the ribosome [40]. Omacetaxine blocks the elongation process of protein
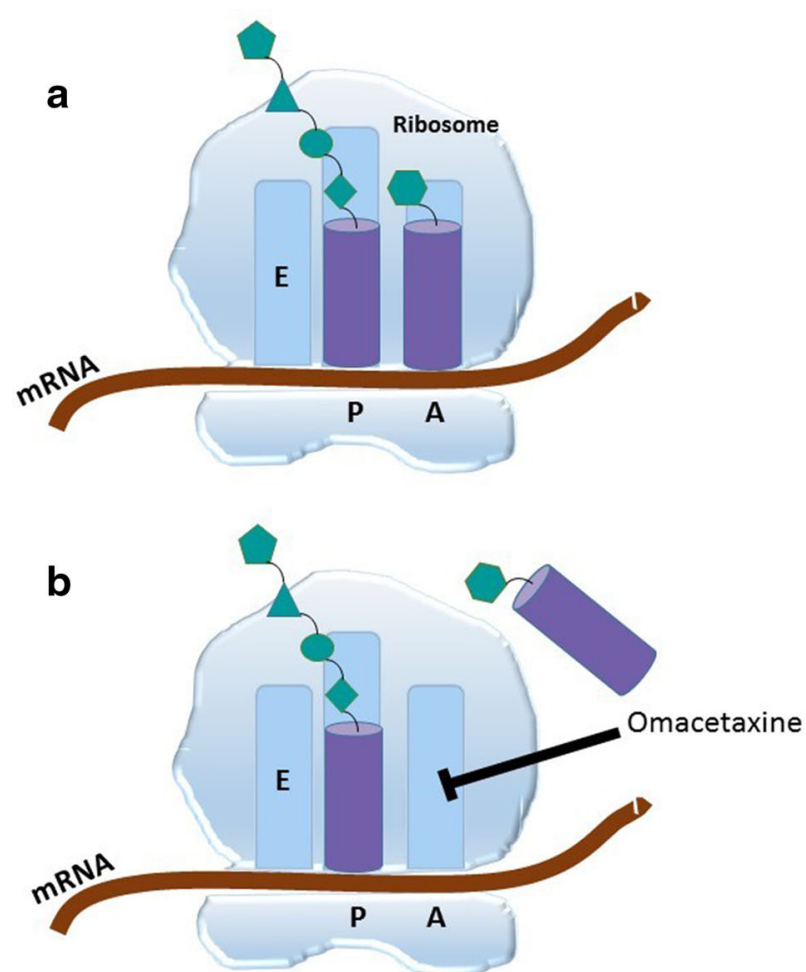

Fig. 1a-b Normal protein translation involves tRNA with linked amino acids matching with the mRNA at the A site. The nascent peptide chain at the $\mathrm{P}$ site is then transferred to the incoming amino acid and the tRNA is synthesis by competing with tRNA to bind to the A-site cleft in the large ribosomal subunit [41]. This blockade in protein synthesis causes a decrease in proteins, especially those with short half-lives, and cells dependent on these proteins undergo apoptosis. The unique mechanisms of omacetaxine and HHT enable them to be used in cases of TKI-resistant CML.

Murine studies evaluating omacetaxine in CML and B-ALL models demonstrated that > $90 \%$ of leukemic stem cells were killed by omacetaxine in vitro. Mice that were treated with omacetaxine also showed a decrease in leukemic stem cells. This is in stark contrast to TKIs, which do not have any effect on leukemic stem cells. Omacetaxine improved the survival of mice transduced with the T315I mutant of BCR-ABL, and seemed more efficient at inhibiting the T315I mutation than the wildtype BCR-ABL. The study also established that,
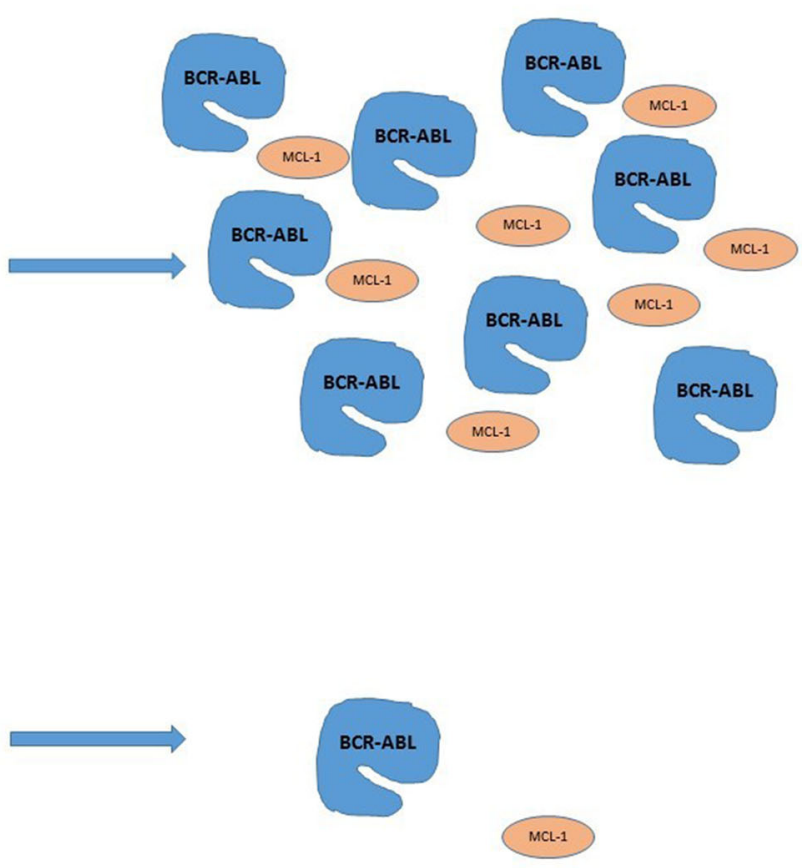

moved to the $\mathrm{P}$ site to enable a new amino-acyl-tRNA to enter the A site (a), leading to further protein translation and protein production. Omacetaxine blocks the A site (b), thereby inhibiting protein synthesis 
in vitro, omacetaxine induced losses of BCRABL, HSP90, and MCL-1 [42].

The inhibition of MCL-1 was further explored by evaluating the signal transduction pathways in BCR-ABL-positive human myeloid cell lines. When omacetaxine was added to CD34-positive cells from patients with and without CML, it was found to inhibit both progenitor and primitive cells, with enhanced killing observed when it was combined with imatinib. Addition of omacetaxine to K562 and CML stem/progenitor cells induced apoptosis, mediated by the downregulation of Mcl-1 [43]. The decrease in Mcl-1 induced Bcl-2 cleavage in cell lines and caused the release of cytochrome c, leading to apoptosis. This effect of omacetaxine on Mcl-1 turnover and the subsequent release of cytochrome $\mathrm{c}$ and apoptosis was not seen with daunorubicin or cytarabine [44]. A later study demonstrated that the decrease in Mcl-1 is only a minor contributor to apoptosis; the inhibition of protein synthesis and apoptosis is thought to be independent of the Bax/ Bak axis [45]. Recent data suggest that omacetaxine [46] may be beneficial in patients with lymphoma, as in vitro studies have demonstrated an induction of cell cycle arrest in G0/ G1, promoted terminal differentiation of pro-B cells, and an antitumor effect due to decreased telomerase activity.

It is expected that HHT, similar to omacetaxine, induces apoptosis. HHT causes upregulation of Bax, leading to an apoptotic response via the activation of caspase-3 [47]. In acute leukemia and CML cell lines, HHT was found to downregulate phosphorylated proteins of JAK2, STAT-5, and AKT, and to decrease Bcl-XL with prolonged exposure [48]. HHT also decreased EphB4 expression in CML cells, and enhanced cell death when added to imatinib [49].

\section{Clinical Pharmacology}

Peak plasma concentrations of omacetaxine are reached approximately $30 \mathrm{~min}$ after injection. Omacetaxine does not inhibit cytochrome P450 enzymes, and it is unclear whether omacetaxine induces cytochrome P450 enzymes. Omacetaxine is a substrate but not an inhibitor of
P-glycoprotein. Early clinical trials did not demonstrate any evidence of QT prolongation. The major elimination route of omacetaxine is unknown, but it is hydrolyzed to an inactive metabolite via plasma esterases and $<15 \%$ is excreted unchanged in the urine. The half-life of omacetaxine is approximately $6 \mathrm{~h} \mathrm{[50].}$

\section{CLINICAL STUDIES OF OMACETAXINE}

\section{Phase I/II Studies}

One of the earliest studies of omacetaxine to be published evaluated patients who achieved a partial or complete cytogenetic response to imatinib [51]. Patients who had been on imatinib (400-600 mg) for at least 2 years and had not reached $\geq 35 \%$ Philadelphia chromosome negativity were treated with omacetaxine at $1.25 \mathrm{mg} / \mathrm{m}^{2}$ subcutaneously twice daily initially for only 1 day, with additional doses given every 2 days if the previous dose was tolerated. Cycles were every 28 days. In this small study, 7 of 10 patients showed a decrease in BCR-ABL transcript levels, 5 of which were greater than 1 $\log$. The regimen was found to be safe, with toxicities of prolonged neutropenia and thrombocytopenia that were dose-related. The most common nonhematologic toxicity was asthenia, which was observed in all patients and lasted 2-3 days after the final dose.

A second phase I/II study evaluated HHT (note: not omacetaxine) in CML; the phase I portion included patients $\geq 12$ years old with CML at any phase, while the phase II portion included only chronic-phase patients [52]. The study utilized an initial loading dose of $2 \mathrm{mg} / \mathrm{m}^{2}$ and varying subcutaneous doses, and eventually settled on a loading dose of $2.5 \mathrm{mg} / \mathrm{m}^{2}$ and a maximum tolerated dose of $1.25 \mathrm{mg} / \mathrm{m}^{2}$ subcutaneously for 14 days total of a 28 -day cycle. In the expansion cohort of 6 patients who failed imatinib, 5 were evaluable, with all having a complete hematologic remission and 3 having a cytogenetic response. It is important to note that this $1.25 \mathrm{mg} / \mathrm{m}^{2}$ dosing was also found to be the dose moving forward with omacetaxine (i.e. semisynthetic HHT), although omacetaxine 
was not used in this study [46]. Hematologic toxicity was again noted, with grade 3-4 anemia (20\%) neutropenia (10\%), and thrombocytopenia (12\%) observed; nonhematologic toxicity was uncommon, with 2 patients presenting with myalgias and fatigue.

\section{Phase II Studies}

Armed with a small subset of data demonstrating efficacy in CML patients who failed imatinib, two studies evaluated the use of omacetaxine in patients with the highly resistant T315I BCR-ABL mutation. In a small study by Nicolini et al., 8 patients with T315I-mutated CML were treated with omacetaxine in order to resensitize the patients to TKIs [53]. Patients were initially dosed at $1.25 \mathrm{mg} / \mathrm{m}^{2}$ twice daily for 14 of 28 days, followed by a 5- to 7-day maintenance cycle every 28 days. Five patients attained a complete hematologic response, and 3 patients had a complete cytogenetic response. All patients experienced grade 3-4 hematologic toxicities in the first cycle and grade $0-2$ hematologic toxicities thereafter. The treatment markedly reduced the T315I clone to below $1 \%$ at a mean of 187 (PCR-RFLP) and 269 (RQ-LNA PCR) days. Only 2 patients received a TKI rechallenge with nilotinib, and 1 patient remained in complete cytogenetic remission.

These study results (Table 1) were further supported by those of a larger study of 62 patients with T315I mutations conducted at MD Anderson using omacetaxine subcutaneously at $1.25 \mathrm{mg} / \mathrm{m}^{2}$ twice daily for 14 days of a 28-day cycle until hematologic remission or a maximum of 6 cycles, then days 1-7 of a 28-day cycle as maintenance [54]. Seventy-seven percent of patients attained a complete hematologic response and 23\% attained a MCyR, including $16 \%$ who achieved a CCyR. In this population, the median progression-free survival was 7.7 months. Toxicity was mainly hematologic, with grade $3 / 4$ toxicities including thrombocytopenia (76\%), neutropenia (44\%), and anemia (39\%).

Another phase II study evaluated omacetaxine in cases of CML-CP resistant to or intolerant of two or more TKIs [55]. Forty-six patients were enrolled; all patients had previously received imatinib, and $59 \%$ of the patients had previously been treated with three or more TKIs. The treatment schedule was identical to the previous study in the T315I-mutated patients, and the primary endpoint was a hematologic response lasting for $>8$ weeks or MCyR. Sixtyseven percent of patients achieved or maintained a hematologic response, with a median duration of 7 months. The MCyR rate was $22 \%$ and the overall cytogenetic response rate (including minor responses) was $37 \%$. As in the prior study, toxicity was mainly hematologic, with grade $3 / 4$ thrombocytopenia, neutropenia, and anemia occurring in 54, 48, and $33 \%$ of patients, respectively. These two studies were published as a pooled analysis of 81 patients with CML-CP. In the total group, $20 \%$ of patients achieved a MCyR, including 8 who attained a CCyR, with a median duration of 17.7 months [56]. As with previous studies, toxicity was primarily hematologic, including thrombocytopenia (67\%), anemia (38\%), and leukopenia (24\%), which were reversible with dose delays. The most common nonhematologic toxicities $\geq$ grade 3 were infection $(12 \%)$, fatigue $(6 \%)$, and gastrointestinal hemorrhage $(4 \%)$.

Since a benefit had been shown in the CMLCP population, a study was performed in patients with accelerated-phase CML (CML-AP) who had failed at least 2 TKIs [57]. It is interesting to note that in this pooled analysis, CML$\mathrm{AP}$ was defined as $15-30 \%$ blasts, $\geq 30 \%$ blasts and promyelocytes, and $\geq 20 \%$ basophils in peripheral blood or bone marrow, platelets < $100 \times 10^{9} / \mathrm{L}$ unrelated to therapy, or clonal evolution. Using the same schedule as employed in the other phase II studies, 41 patients were treated. A major hematologic response (MaHR) was achieved in $27 \%$, with a median MaHR duration of 9 months. None of the patients achieved a CCyR or MCyR, and toxicity rates were similar to those in the previous trials.

In what was deemed the "final analysis of the efficacy and safety of omacetaxine," Cortes et al. published a pooled analysis of 81 CML-AP and CML-CP patients refractory to or unable to tolerate two or more TKIs at the 24-month follow- 
Table 3 Dose administration and dose reductions of omacetaxine [60]

\begin{tabular}{ll}
\hline Induction dosing & $1.25 \mathrm{mg} / \mathrm{m}^{2}$ subcutaneously $\mathrm{q} 12 \mathrm{~h}$ for 14 days over a 28 -day cycle \\
& Cycles repeated until patient achieves a hematologic response \\
Maintenance & $1.25 \mathrm{mg} / \mathrm{m}^{2}$ subcutaneously $\mathrm{q} 12 \mathrm{~h}$ for 7 days over a 28 -day cycle \\
dosing & Treatment continues as long as patients are receiving a clinical benefit \\
Dose delay/ & If grade 4 neutropenia $\left(\mathrm{ANC}<0.5 \times 10^{9} / \mathrm{L}\right)$ or grade 3 thrombocytopenia $\left(\mathrm{PLT}<50 \times 10^{9} / \mathrm{L}\right)$ \\
reduction & occurs, delay the initiation of the next cycle until ANC $\geq 1.0 \times 10^{9} / \mathrm{L}$ and PLT $\geq 50 \times 10^{9} / \mathrm{L}$ \\
& For subsequent cycles, reduce the number of dosing days by $2($ to 12 or 5 days $)$ \\
Monitoring & Induction cycles: weekly CBC \\
& First maintenance: weekly CBC \\
& Subsequent maintenance: fortnightly CBC
\end{tabular}

$A N C$ absolute neutrophil count, $P L T$ platelets, $C B C$ complete blood count with differential

up [58]. In the CML-CP patients, the MCyR rate was unchanged at 20\% (CCyR 8\%), with a median response duration of 12.5 months. In this group, the median overall survival (OS) was 40.3 months. The CML-AP had a MaHR of $14 \%$, with an OS of 24.6 months. In the study, 9 of 81 (11\%) CML-CP patients advanced to bone marrow transplant, compared to none of the CML-AP patients. Although only a small number of these patients were able to use this treatment as a bridge to transplant, this may be the most vital role for the use of omacetaxine.

\section{FDA Approval}

Based on the data from these studies, the FDA granted accelerated approval of omacetaxine mepesuccinate (Synribo ${ }^{\text {TM }}$, Teva Pharmaceuticals, USA) on October 26, 2012 specifically for CML-CP or CML-AP cases with resistance or intolerance to two or more TKIs [50]. Approval was based on the response rates noted above in a total of 158 patients, with follow-ups of 19.5 months for the CML-CP population and 11.5 months for the CML-AP population. Also noted in the FDA report was the fact that the safety profile could not be fully evaluated because of the lack of a control arm in each of these trials; it was difficult to conclude if specific adverse effects were due to the disease or drug. The FDA had significant concerns about patient reconstitution of omacetaxine due to the harmful fumes released and the danger of toxic spills contaminating patient homes. Therefore, the approval was also conditional on patients receiving the first treatment at a medical facility daily for up to 14 days, with the second dose administered at the patient's home by a home care nurse. Treatment is based on induction and maintenance schedules, with strict guidelines for dose delays and reductions (Table 3). Currently, omacetaxine is only approved for usage in the United States.

\section{REAL-WORLD USE OF OMACETAXINE}

Based on the FDA approval guidelines and restrictions on omacetaxine, there is a limited albeit well-defined population that is eligible for omacetaxine. In our practice, most of the patients that have been refractory or intolerant to two or more TKIs have either harbored the T315I mutation or were unable to tolerate the TKIs due to adverse effects. This highly TKI-refractory population has limited options, including ponatinib (if T315I), omacetaxine, or enrollment on a clinical trial. In this resistant population, omacetaxine is typically used as a bridge to SCT. Most patients tolerate omacetazine well, and the side effects reported are 
similar to those already reported from clinical trials, such as injection-site reactions, cytopenias, and infections. Cytopenias can be managed by treatment delays (see Table 3), administration of growth factors, and transfusion support [59]. Laboratory studies should be obtained twice weekly when the patient is initially placed on the medication, and if the patient advances to maintenance, laboratory studies should be evaluated every 1-2 weeks.

The largest hurdle once omacetaxine was initially approved was the FDA mandate that patients receive the first of each daily treatment in a medical facility. This regulation was logistically difficult for the vast majority of patients given the distance to their care center, and many centers do not have weekend hours. In order to comply with the FDA mandate and enable patients to receive some of the treatments at home, Teva Pharmaceuticals created the SYNCare program. This program arranges the direct delivery of the medication to the patient's home, provides educational and injection training material, and has a 24-h hotline to address all patient questions or issues. This service also provides equipment for proper disposal and cleaning should a spill occur. The first dose must still be given at the prescribing center, with appropriate local teaching. The SYNCare program fulfils the FDA requirement of having a healthcare professional prepare and reconstitute the omacetaxine, but it permits subsequent dosing at the patient's home (www. synribo.com/SYNCare_Support).

\section{CONCLUSION}

Although the mainstay of CML treatment is TKI-based therapy, which has led to an improvement in the overall survival of this population, omacetaxine is a viable option for a select population of TKI-resistant or TKI-intolerant patients. In our practice, we prescribe omacetaxine for patients who have exhausted all standard TKI options. Omacetaxine can be effective for hematologic disease control, although the rate of CCyR is low, and there is a lack of reports of molecular responses. Hematologic toxicity is usually well mitigated by dose-reduction guidelines. Given the novel mechanism of action of omacetaxine, it provides a therapeutic option for patients who are intolerant or resistant to multiple TKIs.

\section{ACKNOWLEDGEMENTS}

Funding. No funding or sponsorship was received for this study or the publication of this article.

Authorship. All named authors meet the International Committee of Medical Journal Editors (ICMJE) criteria for authorship for this article, take responsibility for the integrity of the work as a whole, and have given their approval for this version to be published.

Disclosures. Eric S. Winer has nothing to disclose. Daniel J. DeAngelo has received honoraria for advisory boards from Novartis, BMS, Takeda, and Pfizer.

Compliance with Ethics Guidelines. This article is based on previously conducted studies and does not contain any studies with human participants or animals performed by any of the authors.

Open Access. This article is distributed under the terms of the Creative Commons Attribution-NonCommercial 4.0 International License (http://creativecommons.org/licenses/ by-nc/4.0/), which permits any noncommercial use, distribution, and reproduction in any medium, provided you give appropriate credit to the original author(s) and the source, provide a link to the Creative Commons license, and indicate if changes were made.

\section{REFERENCES}

1. Nowell PC, Hungerford DA. A minute chromosome in human chronic granulocytic leukemia. Science (New York, NY). 1960;132(3438):1497. 
2. Daley GQ, Van Etten RA, Baltimore D. Induction of chronic myelogenous leukemia in mice by the P210bcr/abl gene of the Philadelphia chromosome. Science (New York, NY). 1990;247(4944):824-30.

3. Lugo TG, Pendergast AM, Muller AJ, Witte ON. Tyrosine kinase activity and transformation potency of bcr-abl oncogene products. Science (New York, NY). 1990;247(4946):1079-82.

4. Kantarjian HM, O'Brien S, Cortes J. Homoharringtonine/omacetaxine mepesuccinate: the long and winding road to Food and Drug Administration approval. Clin Lymphoma Myeloma Leuk. 2013;13(5):530-3.

5. Warrell RP Jr, Coonley CJ, Gee TS. Homoharringtonine: an effective new drug for remission induction in refractory nonlymphoblastic leukemia. J Clin Oncol. 1985;3(5):617-21.

6. Stewart JA, Cassileth PA, Bennett JM, O'Connell MJ. Continuous infusion homoharringtonine (NSC 141633) in refractory acute nonlymphocytic leukemia. An ECOG pilot study. Am J Clin Oncol. 1988;11(6):627-9.

7. Feldman E, Arlin Z, Ahmed T, Mittelman A, Puccio $\mathrm{C}$, Chun $\mathrm{H}$, et al. Homoharringtonine is safe and effective for patients with acute myelogenous leukemia. Leukemia. 1992;6(11):1185-8.

8. Kantarjian HM, Keating MJ, Walters RS, Koller CA, McCredie KB, Freireich EJ. Phase II study of lowdose continuous infusion homoharringtonine in refractory acute myelogenous leukemia. Cancer. 1989;63(5):813-7.

9. Kantarjian H, O'Brien S, Jabbour E, Barnes G, Pathak A, Cortes J. Effectiveness of homoharringtonine (omacetaxine mepesuccinate) for treatment of acute myeloid leukemia: a meta-analysis of Chinese studies. Clin Lymphoma Myeloma Leuk. 2015;15(1):13-21.

10. Feldman EJ, Seiter KP, Ahmed T, Baskind P, Arlin ZA. Homoharringtonine in patients with myelodysplastic syndrome (MDS) and MDS evolving to acute myeloid leukemia. Leukemia. 1996;10(1):40-2.

11. O'Brien S, Kantarjian H, Keating M, Beran M, Koller C, Robertson LE, et al. Homoharringtonine therapy induces responses in patients with chronic myelogenous leukemia in late chronic phase. Blood. 1995;86(9):3322-6.

12. O'Brien S, Kantarjian H, Koller C, Feldman E, Beran $M$, Andreeff $M$, et al. Sequential homoharringtonine and interferon-alpha in the treatment of early chronic phase chronic myelogenous leukemia. Blood. 1999;93(12):4149-53.
13. O'Brien S, Talpaz M, Cortes J, Shan J, Giles FJ, Faderl $S$, et al. Simultaneous homoharringtonine and interferon-alpha in the treatment of patients with chronic-phase chronic myelogenous leukemia. Cancer. 2002;94(7):2024-32.

14. Kantarjian HM, Talpaz M, Smith TL, Cortes J, Giles FJ, Rios MB, et al. Homoharringtonine and low-dose cytarabine in the management of late chronicphase chronic myelogenous leukemia. J Clin Oncol. 2000;18(20):3513-21.

15. Stone RM, Donohue KA, Stock W, Hars V, Linker CA, Shea T, et al. A phase II study of continuous infusion homoharringtonine and cytarabine in newly diagnosed patients with chronic myeloid leukemia: CALGB study 19804. Cancer Chemother Pharmacol. 2009;63(5):859-64.

16. O'Brien S, Giles F, Talpaz M, Cortes J, Rios MB, Shan $J$, et al. Results of triple therapy with interferonalpha, cytarabine, and homoharringtonine, and the impact of adding imatinib to the treatment sequence in patients with Philadelphia chromosome-positive chronic myelogenous leukemia in early chronic phase. Cancer. 2003;98(5):888-93.

17. Kantarjian H, Sawyers C, Hochhaus A, Guilhot F, Schiffer C, Gambacorti-Passerini C, et al. Hematologic and cytogenetic responses to imatinib mesylate in chronic myelogenous leukemia. $\mathrm{N}$ Engl J Med. 2002;346(9):645-52.

18. Hughes TP, Kaeda J, Branford S, Rudzki Z, Hochhaus A, Hensley ML, et al. Frequency of major molecular responses to imatinib or interferon alfa plus cytarabine in newly diagnosed chronic myeloid leukemia. N Engl J Med. 2003;349(15):1423-32.

19. O'Brien SG, Guilhot F, Larson RA, Gathmann I, Baccarani M, Cervantes F, et al. Imatinib compared with interferon and low-dose cytarabine for newly diagnosed chronic-phase chronic myeloid leukemia. N Engl J Med. 2003;348(11):994-1004.

20. Druker BJ, Guilhot F, O'Brien SG, Gathmann I, Kantarjian H, Gattermann N, et al. Five-year followup of patients receiving imatinib for chronic myeloid leukemia. $\mathrm{N}$ Engl J Med. 2006;355(23):2408-17.

21. Hochhaus A, Larson RA, Guilhot F, Radich JP, Branford S, Hughes TP, et al. Long-term outcomes of imatinib treatment for chronic myeloid leukemia. N Engl J Med. 2017;376(10):917-27.

22. Hochhaus A, O'Brien SG, Guilhot F, Druker BJ, Branford S, Foroni L, et al. Six-year follow-up of patients receiving imatinib for the first-line treatment of chronic myeloid leukemia. Leukemia. 2009;23(6):1054-61. 
23. Hochhaus A, Kantarjian HM, Baccarani M, Lipton JH, Apperley JF, Druker BJ, et al. Dasatinib induces notable hematologic and cytogenetic responses in chronic-phase chronic myeloid leukemia after failure of imatinib therapy. Blood. 2007;109(6):2303-9.

24. Kantarjian H, Shah NP, Hochhaus A, Cortes J, Shah $\mathrm{S}$, Ayala M, et al. Dasatinib versus imatinib in newly diagnosed chronic-phase chronic myeloid leukemia. N Engl J Med. 2010;362(24):2260-70.

25. Saglio G, Kim DW, Issaragrisil $S$, le Coutre P, Etienne $G$, Lobo $C$, et al. Nilotinib versus imatinib for newly diagnosed chronic myeloid leukemia. N Engl J Med. 2010;362(24):2251-9.

26. Kantarjian HM, Giles F, Gattermann N, Bhalla K, Alimena G, Palandri F, et al. Nilotinib (formerly AMN107), a highly selective BCR-ABL tyrosine kinase inhibitor, is effective in patients with Philadelphia chromosome-positive chronic myelogenous leukemia in chronic phase following imatinib resistance and intolerance. Blood. 2007;110(10):3540-6.

27. Brummendorf TH, Cortes JE, de Souza CA, Guilhot F, Duvillie L, Pavlov D, et al. Bosutinib versus imatinib in newly diagnosed chronic-phase chronic myeloid leukaemia: results from the 24-month follow-up of the BELA trial. $\mathrm{Br} \mathrm{J}$ Haematol. 2015;168(1):69-81.

28. Cortes JE, Gambacorti-Passerini C, Deininger MW, Mauro MJ, Chuah C, Kim DW, et al. Bosutinib versus imatinib for newly diagnosed chronic myeloid leukemia: results from the randomized BFORE trial. J Clin Oncol. 2018;36(3):231-237.

29. Cortes JE, Kantarjian HM, Brümmendorf TH, Kim D-W, Turkina AG, Shen Z-X, et al. Safety and efficacy of bosutinib (SKI-606) in chronic phase Philadelphia chromosome-positive chronic myeloid leukemia patients with resistance or intolerance to imatinib. Blood. 2011;118(17):4567-76.

30. Cortes JE, Kantarjian H, Shah NP, Bixby D, Mauro MJ, Flinn I, et al. Ponatinib in refractory Philadelphia chromosome-positive leukemias. N Engl J Med. 2012;367(22):2075-88.

31. Lipton JH, Chuah C, Guerci-Bresler A, Rosti G, Simpson D, Assouline S, et al. Ponatinib versus imatinib for newly diagnosed chronic myeloid leukaemia: an international, randomised, open-label, phase 3 trial. Lancet Oncol. 2016;17(5):612-21.

32. Bhamidipati PK, Kantarjian H, Cortes J, Cornelison AM, Jabbour E. Management of imatinib-resistant patients with chronic myeloid leukemia. Ther Adv Hematol. 2013;4(2):103-17.
33. Redaelli S, Piazza R, Rostagno R, Magistroni V, Perini P, Marega M, et al. Activity of bosutinib, dasatinib, and nilotinib against 18 imatinib-resistant BCR/ABL mutants. J Clin Oncol. 2009;27(3):469-71.

34. O'Hare T, Shakespeare WC, Zhu X, Eide CA, Rivera VM, Wang F, et al. AP24534, a pan-BCR-ABL inhibitor for chronic myeloid leukemia, potently inhibits the T315I mutant and overcomes mutationbased resistance. Cancer Cell. 2009;16(5):401-12.

35. Zabriskie MS, Eide CA, Tantravahi SK, Vellore NA, Estrada J, Nicolini FE, et al. BCR-ABL1 compound mutations combining key kinase domain positions confer clinical resistance to ponatinib in Ph chromosome-positive leukemia. Cancer Cell. 2014;26(3):428-42.

36. Eide CA, O'Hare T. Chronic myeloid leukemia: advances in understanding disease biology and mechanisms of resistance to tyrosine kinase inhibitors. Curr Hematol Malig Rep. 2015;10(2):158-66.

37. Patel AB, $\mathrm{O}^{\prime}$ Hare $\mathrm{T}$, Deininger MW. Mechanisms of resistance to $\mathrm{ABL}$ kinase inhibition in chronic myeloid leukemia and the development of next generation ABL kinase inhibitors. Hematol Oncol Clin North Am. 2017;31(4):589-612.

38. Barnes DJ, Palaiologou D, Panousopoulou E, Schultheis B, Yong ASM, Wong A, et al. Bcr-Abl expression levels determine the rate of development of resistance to imatinib mesylate in chronic myeloid leukemia. Can Res. 2005;65(19):8912-9.

39. Robin JDR, Dujardin G, Poutot S. The first semisynthesis of enantiopure homoharringtonine via anhydrohomoharringtonine from a preformed chiral acyl moiety. Tetrahedron Lett. 1999;40(15):2931-4.

40. Gandhi V, Plunkett W, Cortes JE. Omacetaxine: a protein translation inhibitor for treatment of chronic myelogenous leukemia. Clin Cancer Res. 2014;20(7):1735-40.

41. Gurel G, Blaha G, Moore PB, Steitz TA. U2504 determines the species specificity of the A-site cleft antibiotics: the structures of tiamulin, homoharringtonine, and bruceantin bound to the ribosome. J Mol Biol. 2009;389(1):146-56.

42. Chen Y, Hu Y, Michaels S, Segal D, Brown D, Li S. Inhibitory effects of omacetaxine on leukemic stem cells and BCR-ABL-induced chronic myeloid leukemia and acute lymphoblastic leukemia in mice. Leukemia. 2009;23(8):1446-54.

43. Allan EK, Holyoake TL, Craig AR, Jorgensen HG. Omacetaxine may have a role in chronic myeloid leukaemia eradication through downregulation of 
Mcl-1 and induction of apoptosis in stem/progenitor cells. Leukemia. 2011;25(6):985-94.

44. Tang R, Faussat AM, Majdak P, Marzac C, Dubrulle $S$, Marjanovic Z, et al. Semisynthetic homoharringtonine induces apoptosis via inhibition of protein synthesis and triggers rapid myeloid cell leukemia-1 down-regulation in myeloid leukemia cells. Mol Cancer Ther. 2006;5(3):723-31.

45. Lindqvist LM, Vikstrom I, Chambers JM, McArthur K, Ann Anderson M, Henley KJ, et al. Translation inhibitors induce cell death by multiple mechanisms and Mcl-1 reduction is only a minor contributor. Cell Death Dis. 2012;3:e409.

46. Zhang L, Chen Z, Zuo W, Zhu X, Li Y, Liu X, et al. Omacetaxine mepesuccinate induces apoptosis and cell cycle arrest, promotes cell differentiation, and reduces telomerase activity in diffuse large B-cell lymphoma cells. Mol Med Rep. 2016;13(4):3092-100.

47. Yinjun L, Jie J, Weilai X, Xiangming T. Homoharringtonine mediates myeloid cell apoptosis via upregulation of pro-apoptotic bax and inducing caspase-3-mediated cleavage of poly(ADP-ribose) polymerase (PARP). Am J Hematol. 2004;76(3):199-204.

48. Tong H, Ren Y, Zhang F, Jin J. Homoharringtonine affects the JAK2-STAT5 signal pathway through alteration of protein tyrosine kinase phosphorylation in acute myeloid leukemia cells. Eur J Haematol. 2008;81(4):259-66.

49. Huang BT, Zeng QC, Zhao WH, Tan Y. Homoharringtonine contributes to imatinib sensitivity by blocking the EphB4/RhoA pathway in chronic myeloid leukemia cell lines. Med Oncol (Northwood, London, England). 2014;31(2):836.

50. Alvandi F, Kwitkowski VE, Ko CW, Rothmann MD, Ricci S, Saber H, et al. U.S. Food and Drug Administration approval summary: omacetaxine mepesuccinate as treatment for chronic myeloid leukemia. Oncologist. 2014;19(1):94-9.

51. Marin D, Kaeda JS, Andreasson C, Saunders SM, Bua $\mathrm{M}$, Olavarria E, et al. Phase I/II trial of adding semisynthetic homoharringtonine in chronic myeloid leukemia patients who have achieved partial or complete cytogenetic response on imatinib. Cancer. 2005;103(9):1850-5.

52. Quintas-Cardama A, Kantarjian H, Garcia-Manero G, O'Brien S, Faderl S, Estrov Z, et al. Phase I/II study of subcutaneous homoharringtonine in patients with chronic myeloid leukemia who have failed prior therapy. Cancer. 2007;109(2):248-55.

53. Nicolini FE, Chomel JC, Roy L, Legros L, Chabane $\mathrm{K}$, Ducastelle $\mathrm{S}$, et al. The durable clearance of the T315I BCR-ABL mutated clone in chronic phase chronic myelogenous leukemia patients on omacetaxine allows tyrosine kinase inhibitor rechallenge. Clin Lymphoma Myeloma Leuk. 2010;10(5):394-9.

54. Cortes J, Lipton JH, Rea D, Digumarti R, Chuah C, Nanda N, et al. Phase 2 study of subcutaneous omacetaxine mepesuccinate after TKI failure in patients with chronic-phase CML with T315I mutation. Blood. 2012;120(13):2573-80.

55. Cortes J, Digumarti R, Parikh PM, Wetzler M, Lipton $\mathrm{JH}$, Hochhaus A, et al. Phase 2 study of subcutaneous omacetaxine mepesuccinate for chronicphase chronic myeloid leukemia patients resistant to or intolerant of tyrosine kinase inhibitors. Am J Hematol. 2013;88(5):350-4.

56. Cortes JE, Nicolini FE, Wetzler M, Lipton JH, Akard L, Craig A, et al. Subcutaneous omacetaxine mepesuccinate in patients with chronic-phase chronic myeloid leukemia previously treated with 2 or more tyrosine kinase inhibitors including imatinib. Clin Lymphoma Myeloma Leuk. 2013;13(5):584-91.

57. Nicolini FE, Khoury HJ, Akard L, Rea D, Kantarjian $\mathrm{H}$, Baccarani $\mathrm{M}$, et al. Omacetaxine mepesuccinate for patients with accelerated phase chronic myeloid leukemia with resistance or intolerance to two or more tyrosine kinase inhibitors. Haematologica. 2013;98(7):e78-9.

58. Cortes JE, Kantarjian HM, Rea D, Wetzler M, Lipton $\mathrm{JH}$, Akard L, et al. Final analysis of the efficacy and safety of omacetaxine mepesuccinate in patients with chronic- or accelerated-phase chronic myeloid leukemia: results with 24 months of follow-up. Cancer. 2015;121(10):1637-44.

59. Akard L, Kantarjian HM, Nicolini FE, Wetzler M, Lipton JH, Baccarani $\mathrm{M}$, et al. Incidence and management of myelosuppression in patients with chronic- and accelerated-phase chronic myeloid leukemia treated with omacetaxine mepesuccinate. Leuk Lymphoma. 2016;57(3):654-65.

60. Teva Pharmaceuticals USA, Inc. Synribo ${ }^{\mathrm{TM}}$. North Wales, PA: Teva Pharmaceuticals USA, Inc.; 2015. http://www.synribo.com/pdf/synribo_pi.pdf. 